\title{
Reinforcing Comprehensive Business Learning Through An Undergraduate Retailing Course: A Prospectus
}

Irfan Ahmed, Sam Houston State University, USA

\begin{abstract}
Undergraduate programs in business are expected to provide a comprehensive learning for their students in order to prepare them to be able to deal with complex business problems in their jobs. Business schools attempt to provide this learning through various curricular design strategies. This paper proposes the use of an undergraduate course in retailing to help in achieving the objective of comprehensive learning about the operation of business enterprises, especially for marketing majors. A case is made that a well-designed retailing course provides the potential for reinforcing learning achieved in other marketing courses, creates an opportunity for crossfunctional business learning, and can also help in achievement of learning goals specified by $A A C S B$.
\end{abstract}

Keywords: retailing education; marketing courses; undergraduate business education

\section{INTRODUCTION}

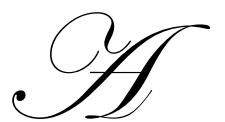

s part of the effort to inculcate a well-rounded understanding of business practice and developing managerial competencies, colleges of business require a course complement that is considered comprehensive, and that covers the major areas of business activity. According to the expectations set by AACSB International, undergraduate degree programs (bachelor's level) in business are expected to "...educate students in a broad range of knowledge and skills as a basis for careers in business" (AACSB 2008, pp.62). In addition to a core curriculum defined at the university level and constituting a general education, students in schools of business are expected to receive learning in management specific areas, such as accounting, management science, marketing, human resources, operations management and, depending on the school, other related disciplines (AACSB 2008). Normally, the required courses in an undergraduate business program are the basic survey level courses in each of the business disciplines; these courses provide grounding in the essential principles of the respective disciplines. Thus, the undergraduate business student is expected to take courses, such as principles of accounting, economics, finance, management, management information systems, marketing, and production operations. Beyond these courses, the student then takes (not necessarily sequentially), required courses in the chosen major and electives from within or outside the major. Recognizing the need for an integrative closure, disciplines, such as management and marketing further require a capstone course or senior project, normally taken in the last semester before graduation, and intended to refresh learning from prior business courses and to allow the student to appreciate the linkages between the content of courses taken within the business disciplines.

Thus, during their junior and senior years, students are exposed to a diverse body of knowledge from the business disciplines. While the sum of courses taken is supposed to ensure a well-rounded exposure to all the major areas of business operations, there is reason to believe that the whole is not equal to the sum of its parts, much less a synergistic quantity. What can be done to engender integrative, cross functional learning among undergraduates before they graduate? This paper proposes that the retailing management course, taken close to graduation, can serve as a platform for students to attain comprehensive learning in critical areas. This paper explores the need for crossfunctional, integrative learning, assesses the ways in which this is currently being sought to be achieved, and offers a 
prospectus for the retailing course in providing a cross-functional learning experience to the undergraduate business student, especially those majoring in marketing.

\section{THE NEED FOR CROSS-FUNCTIONAL LEARNING}

As businesses place increasing emphasis on cross-functional teams, there is an expectation that employees will fulfill roles that are cross functional (DeMoranville, Aurand and Gordon 2000). While cross-functional teams and cross-functional abilities are desirable in larger organizations, they are absolute necessities in smaller organizations and also in the not-for-profit sector where the employment of a functionally varied staff is a luxury. However, as DeMoranville, Aurand and Gordon (2000) say, a hindrance in businesses developing making their organizations more cross-functional has been employees' lack of experience with cross-functional teams and their predominant identification with their own functional area.

For over a decade now, MBA programs have been under pressure to equip graduates with cross-functional abilities to be able to better tackle the realities of the business world (Corsini et al. 2000; DeConinck and Steiner 1999; Marshall, Bolten and Solomon 2000). Consequently, a number of MBA programs have created crossfunctional courses (DeMoranville, Aurand and Gordon 2000). Smart et al. (1999) note that distinctions between undergraduate and graduate business education are blurring in terms of pedagogy and content; thus, it is desirable that undergraduate business majors also develop cross-functional abilities through their curriculum. Butler and Straughn-Mizerski (1998) reported that since a decade ago, some business schools (e.g., University of Virginia and Pennsylvania State University) have been offering courses that incorporate the business curriculum in integrated units - courses that may be taught over multiple semesters and by a team of faculty. Such courses cover not only the content of multiple areas, such as management, finance, accounting, etc., but also focus on the interrelationships between and across the various functional areas. It is evident that business schools are increasingly recognizing the need for cross-functional education, and several have taken the initiative to develop cross-functional business courses and programs (see Corsini et al. 2000 and DeMoranville, Aurand and Gordon 2000 for their experiences developing such courses).

Marketing is, inarguably, a boundary-spanning function in the business or not-for-profit organization. Hence, marketing functionaries need to be cognizant of the linkages between the marketing function and the other functions in the organization. For instance, marketers need to be aware of the cost impact and profit contribution of their activities on the organization's financial performance, and in areas, such as customer lifetime value assessment. However, a lack of fundamental finance skills keeps marketing students from fully grasping the linkage (Abernethy and Gray 2000). Similarly, an intuitive and calculative usage of accounting has been observed in the management of customer relationships (Cuganesan 2008), and the ability to integrate learning from accounting courses would prove to be useful. What is the degree and extent of cross-functional exposure of marketing majors? In a survey of marketing department chairs, Crittenden and Wilson (2006) found that cross-functional learning has received some level of support within marketing departments, and respondents recognized the necessity of cross-functional learning and saw it as a competitive advantage for students. Respondents indicated that students were encouraged to apply knowledge from other business courses - especially those in the areas of accounting, finance, organizational behavior, operations, and information systems. Crittenden and Wilson (2006) identified impediments to crossfunctional learning as: student apathy towards applying learning from other courses, perceived lack of cooperation between faculty in different areas, and marketing faculty not doing a good job of ensuring cross-functional learning through appropriate pedagogy. Crittenden and Wilson (2006) note: "Programmatically, there appears to be little creativity in classroom attempts to facilitate cross-functional interactions.... While the rationale is strong for crossfunctionality, curricula efforts appear woefully inadequate." (pp. 84). Crittenden and Wilson (2006) note that crossfunctional learning is necessary, and needs to be made more prevalent in undergraduate business programs.

There have been calls for greater cross functional training that takes the student beyond the technical learning of the major, towards greater awareness of the overall functioning of business organizations and an appreciation of the linkages between different disciplinary areas. Ahadiat (2008), summarizing the findings of a survey of management accounting professionals, notes that in addition to technical accounting knowledge, graduates need to develop skills in strategy and organization, and that the accounting curriculum needs to incorporate more interdisciplinary content in the management accounting education. According to Kavanagh and Drennan (2008), 
while employers of accounting graduates expect accounting skills and analytical abilities, they also would like to see greater business awareness and real-world knowledge. In the Management Information Systems (MIS) discipline, taking a double-major i.e., MIS and another discipline, has become a strategy used by students to improve their employment prospects (Fang et al. 2004).

\section{THE NEED FOR CONTENT REINFORCEMENT}

The average business student takes approximately 120 credit hours over his/her degree plan, with about half of those credit hours coming from the business curriculum and the other half from outside the discipline as per AACSB guidelines. Some of those non-business hours include courses in mathematics and economics, areas essential for developing reasoning skills and understanding the foundations of business, respectively. Competencies in mathematics and accounting have also been identified as necessary in retailing jobs (Hudson 1978). However, the degree to which material from these courses is remembered by students through the remainder of their degree program remains questionable; the degree to which material is remembered after graduation is even dubious. A similar situation applies to the content of courses in the business disciplines e.g., accounting and finance (Gifford 1986). Besides the compartmentalization of course content, a likely reason for this seepage of learning is a lack of reinforcement through rehearsal of the conceptual content and the consequent forgetting of material that is not used Anderson 1990). Such forgetting of learning may be mitigated by reinforcement of the learning through repeated exposure.

Reinforcement of learning through repetition has been identified as a practice of significant value in education (Eggen and Kauchak 2006). Two reinforcement of learning strategies have been identified in the literature - traditional and rolling (Mukherjee 2002). In traditional reinforcement, the repetition of content is done the same day by the instructor, whereas in rolling reinforcement, repetition of content is done at a date later than the date of first exposure to content. Of the two strategies, rolling reinforcement has been found to lead to superior improvement in student performance (Mukherjee 2002). This confirms a view held by educators that the efficiency of learning is higher when it is spread over several periods of time rather than being compressed into one (Anderson 1990). The retailing course provides an opportunity for reinforcement of learning at a time removed from initial exposure to the content in courses in the respective areas. This programmatic rolling reinforcement of course material could potentially stave off the natural attrition of learning that would occur due to a lack of use of the learning attained.

\section{THE CAPSTONE COURSE}

A capstone course, intended to be taken in the last semester of a student's tenure, and a requirement for graduation, is intended to be an integrative academic experience that brings together learning acquired in previous courses and that brings the student closer to a future career. Capstone courses are prevalent in several business disciplines -- accounting (Burns 2006; Jervis and Hartley 2005), finance (Nofsinger 1995), information systems (Beachboard and Beard 2005; Wei, Siow and Burley 2007) and management (Doyle Corner et al. 2006). Capstone courses in marketing are intended to be integrative of learning that typically begins with the principles of marketing course and progresses through required and elective courses that include consumer behavior, marketing research, advertising and promotion, retailing, international marketing, personal selling and distribution, among others. These courses are normally taught independently, often by different faculty, with little interaction between courses (Butler and Straughn- Mizerski 1998). Thus, the need for a capstone course is all the greater, to weave a web through the content of the various courses and enable students to see the linkages between the content of the courses they have taken. While there is considerable variation in capstone course design and execution, and even in the name of the course, commonalities include a central core comprising the marketing mix, an underlying theme of the interactions between the firm and its customers, and an introduction to strategic market planning frameworks (Bussière 2005). In an extensive study of syllabi of capstone courses, Crittenden and Crittenden (2006) found that the leading learning outcomes related to course materials were: understanding marketing concepts, integration of previously learned marketing concepts, cross-functional integration and developing an understanding of the role of marketing in business. In terms of skill development, the leading outcomes were found to be: the use of analytical process and planning, critical thinking and problem solving, and the enhancement of communication, decision-making, planning and implementation skills. Crittenden and Crittenden (2006) found a variety of pedagogical and learning assessment 
tools in use; in addition to lectures, there was considerable use of cases, activities involving teamwork, in-class discussions and experiential exercises. Case analyses and projects are commonly used as assessment methods, in addition to exams. In addition to providing an abbreviated review of the basic content of the discipline found in previous courses, there appears to be a conscious effort in the capstone course to enhance students' critical thinking, problem solving skills and analytical abilities.

Is the single capstone course sufficient for accomplishing the objective of achieving integrative learning? Irrespective of the major, the capstone course intended to be taken in the last semester of a student's academic program. Though it seeks to reinforce prior learning in the major and to incorporate cross-functional content, it may be argued that for achieving these goals, two courses may be better than one. Reinforcement through repetition is a desirable goal for ensuring learning (Eggen and Kauchak 2006), and reinforcement twice is likely to better than once. Further, considering the greater efficacy of rolling reinforcement, multiple opportunities for reinforcement separated in time could potentially be more efficacious than one single opportunity. Another reason to consider the contribution of a capstone-like course is the fact that the capstone courses are required only for majors in the respective areas, and these majors receive priority in enrollment for the course if class capacity is limited. Students from outside a major may not take it out of choice or constraints of availability. Thus, the benefits of a marketing capstone may not be available to non-marketing majors, who could potentially benefit from a retailing course that provides integrative, cross-functional learning.

\section{THE RETAILING COURSE: A COMPREHENSIVE LEARNING OPPORTUNITY}

In an early study of the acceptance of retailing as a major, Coe (1978) found marketing faculty respondents largely opposed the requirement of a retailing course for business majors, but also largely favored the requirement of a retailing course for marketing majors. Coe's study found that those opposed to the inclusion of a retailing course indicated the specialized nature of retailing, a low priority and the vocational nature of retailing as reasons for their opposition. On the other hand, those favoring the inclusion of a retailing as part of a business curriculum indicated possible career avenues for students and also the importance of retailing in the economy (Coe 1978). Interestingly, $11 \%$ of respondents indicated duplication between retailing and other courses as a reason for their opposition (Coe 1978). The retailing course, though not offered universally by marketing departments, has been found to be offered in about four out of five marketing departments, and has been found to be the fifth ranking course offered by departments of marketing (Butler and Straughn-Mizerski 1998).

What does a retailing course offer? McKay (1978) pointed to three requisites: pragmatic experience of what a retail job entails, an ability to deal with and manage personnel, and the ability to analyze information.

Students learn consumer behavior from the retailer's perspective, and understand the techniques used by retailers to influence consumer behavior (Stanton 2006). Through project components, such as running a retail store, students can attain real world knowledge and implement learning from their marketing and business courses (see Seitz and Razzouk 2002 for a retailing operation project). According to Stanley Marcus, the late "Prince among Retailers," the most important aspects of retailing are the goods (i.e., merchandising) and customers (Marcus 1978). Marcus, bringing a unique practitioner perspective to the subject of retailing education, stressed the need for retailing students to learn about goods and merchandising (with a cross-functional exposure to manufacturing) and how to take care of customers. In an age when customer service has become a rare commodity, the retailing course has the potential for increasing students' recognition of the need and value of customer service.

The retailing course also has the potential to cover ethical, legal and regulatory issues where the customer actually interfaces with businesses in a transactional encounter. As noted thirty years ago, 'payola' or inducement to sway retailing buyers is one among several ethical issues that pervade retailing (Marcus 1978). Turning the spotlight on these issues would create an excellent opportunity to introduce ethical decision-making in the business curriculum. Legal foundations of retail transactions can help reinforce the basics of contract law and the Uniform Commercial Code (UCC) that may have been covered in a business law course (Pearson and Brockhoeft 2000). This reinforcement is desirable because the business law course covers a variety of business-related topics, and may not pay particular attention to marketing oriented topics; additionally, students may not have been able to appreciate the value of the legal content they learned at a point much earlier in their degree plan (Pearson and Brockhoeft 2000). 
Dickinson (1978) in an early critique of retailing education, observed that retailing education has focused on logical, 'left-brain' learning, with emphasis on analytical tools from the disciplines of management, marketing, and finance. Dickinson (1978) recommended that "Specifically, colleges of business at the four year level should consider offering courses related to product construction, fashion, display, creativity and the like" (pp. 93). The retailing course thus has the ability to expose students to aspects of a business that are related to creativity and the application of artistic talent and effort. This is an excellent opportunity - to be seized via the deployment of handson exercises in the design and evaluation of merchandising and design elements of a retail operation - to encourage 'right brain thinking,' an ability that has been found lacking in business school curricula due to a dominant paradigmatic focus on rational economic behavior.

Retailers are at the end of the channel of distribution. In this role, they interface not only with consumers who buy from them but also the supply chain that moves merchandise through retailers. Richey, Skinner and Autry (2007) propose an approach to retailing that emphasizes the supply chain role of retailers in addition to their customer-relationship role. The success of businesses depends not only on their relationships with customers, but also on their ability to manage relationships with a variety of business associates, primary among whom are the supply chain partners. The supply-chain decision-making components of the retailing course can increase awareness of the role and value of supply chain management in firm operations, customer satisfaction, and firm profitability. The supply-chain interface can serve as an example of inter-firm relationships in marketing, which are increasingly critical in business due to firms using strategic dyadic or network relationships to replace functions that had traditionally been performed internally. A well designed retailing course - see Richey, Skinner and Autry (2007) for a proposed template - can enable students to appreciate the numerous inter-organizational linkages in a retail operation and their impact on service impact and customer satisfaction.

The value of a retailing course can also be assessed with respect to the achievement of specific learning experiences specified by AACSB International, the accreditation body for schools of business. AACSB International expects the curriculum process to include learning experiences in several specific areas. These include:

- $\quad$ Ethical and legal responsibilities in organizations and society.

- $\quad$ Financial theories, analysis, reporting, and markets.

- Creation of value through the integrated production and distribution of goods, services, and information.

- $\quad$ Group and individual dynamics in organizations.

- $\quad$ Statistical data analysis and management science as they support decision-making processes throughout an organization.

- Information technologies as they influence the structure and processes of organizations and economies, and as they influence the roles and techniques of management.

- Domestic and global economic environments of organizations.

- $\quad$ Other management-specific knowledge and abilities as identified by the school.

$\operatorname{AACSB}(2008$, pp72)

A case has been made in the foregoing sections that the retailing course can accomplish multiple learning goals: the reinforcement of content, integrative cross-functional learning, coverage of content areas not covered in significant detail elsewhere in the curriculum, and the inculcation of 'right-brain', or creative thinking. In addition, it can be shown that a retailing course helps achieve learning in several of the areas identified in AACSB's standards, and can thereby play a part in demonstrating curriculum design features for AACSB accreditation purposes. How does the content of a retailing help in achieving these objectives? An answer to this question may be found by inspecting the content of what is being taught in retailing courses. I do this by considering the topic areas covered in one of the leading texts for the undergraduate retailing courses: Retail Management by Berman and Evans (2008). I consider this a proxy indicator of actual course content since the content coverage in courses typically parallels the coverage of topics in the leading texts of the discipline. The contents of a widely accepted text are likely to be more comprehensive than the coverage chosen by individual instructors, who may vary their topic coverage according to personal preferences and time constraints during the semester. In Table 1, the first column lists the broad content areas taken from Berman and Evans (2008). The first sub-column of the second column indicates if a topic lends 
itself to reinforcement of material covered possibly covered elsewhere in the marketing curriculum, and the course in which it is likely to have been covered. The second sub-column of the second column indicates whether a topic has cross-functional content and the discipline where the content is normally covered. The third sub-column of the second column indicates if the topic contains learning unique to the retailing course. The third column indicates the AACSB specified learning (from the numbered list cited above) that the retailing topic is likely to achieve.

Table 1

Topics in the Retailing Course and Coverage of the Undergraduate Curricular Content

\begin{tabular}{|c|c|c|c|c|}
\hline \multirow[b]{2}{*}{ Topic } & \multicolumn{3}{|c|}{ Nature of Content vis-à-vis other Business Courses } & \multirow[t]{2}{*}{$\begin{array}{c}\text { AACSB } \\
\text { Learning Area } \\
\end{array}$} \\
\hline & $\begin{array}{c}\text { Reinforcement of } \\
\text { marketing area } \\
\text { content }\end{array}$ & $\begin{array}{c}\text { Cross-functional } \\
\text { content }\end{array}$ & $\begin{array}{l}\text { Unique } \\
\text { Content }\end{array}$ & \\
\hline Definition of retailing & Principles & & & 3 \\
\hline Impact of retailing & & & $\mathrm{X}$ & 7 \\
\hline Retail function in distribution & Principles & & & 3 \\
\hline $\begin{array}{l}\text { Relationships among retailers and their } \\
\text { suppliers }\end{array}$ & Principles; Capstone & Management & & 3 \\
\hline Retailing concept & & Management & & 3 \\
\hline The total retail experience & Services Marketing & & & 3 \\
\hline Value and the value chain & & Management & & 3 \\
\hline Retailer relationships & Capstone & Management & & 7 \\
\hline Goods vs services retailing & Services Marketing & & & 8 \\
\hline Technology and relationships & Services Marketing & E-commerce & & 6 \\
\hline Ethical performance and relationships & Principles; Capstone & Management & & 1 \\
\hline Strategic planning & Capstone & Management & & 8 \\
\hline Global retailing & $\begin{array}{l}\text { International } \\
\text { Marketing }\end{array}$ & & & 7 \\
\hline Retail institutions by ownership & & Management & & 7 \\
\hline Store-based strategy mix & Capstone & Strategy & & 3 \\
\hline Web-based retailing & & E-commerce & & 6 \\
\hline Direct marketing, direct selling & $\begin{array}{l}\text { Advertising \& } \\
\text { Promotion }\end{array}$ & & & 3 \\
\hline Multichannel strategy & Capstone & Strategy & & 3 \\
\hline Identifying and understanding customers & $\begin{array}{l}\text { Principles; Consumer } \\
\text { Behavior; Capstone }\end{array}$ & & & 3 \\
\hline Information gathering and processing & $\begin{array}{l}\text { Principles; Marketing } \\
\text { Research }\end{array}$ & $\begin{array}{l}\text { Information } \\
\text { Systems/MIS }\end{array}$ & & 6 \\
\hline Trading area analysis & & & $\mathrm{X}$ & 7 \\
\hline $\begin{array}{l}\text { Retail organization and human resource } \\
\text { management }\end{array}$ & & $\begin{array}{l}\text { Organizational Design/ } \\
\text { Org. Behavior/ HR }\end{array}$ & & 4 \\
\hline Financial dimensions & & Finance & & 2 \\
\hline Operational dimensions & Services Marketing & Operations Management & & 5 \\
\hline Developing merchandise plans & & $\begin{array}{l}\text { Org. Design; Economics; } \\
\text { MIS }\end{array}$ & & 3 \\
\hline Implementing merchandise plans & Distribution & $\begin{array}{l}\text { Management; } \\
\text { Supply Chain }\end{array}$ & & 3 \\
\hline Financial merchandise management & & Finance; MIS & & 2 \\
\hline Pricing & $\begin{array}{l}\text { Principles; Consumer } \\
\text { Behavior; Capstone }\end{array}$ & $\begin{array}{l}\text { Economics; Business } \\
\text { Law }\end{array}$ & & $2,3,5$ \\
\hline Retail image & $\begin{array}{l}\text { Advertising \& } \\
\text { Promotion }\end{array}$ & & & 8 \\
\hline Promotional strategy & $\begin{array}{l}\text { Advertising \& } \\
\text { Promotion }\end{array}$ & & & 8 \\
\hline Integrating and controlling strategy & Capstone & $\begin{array}{l}\text { Accounting; } \\
\text { Management }\end{array}$ & & 8 \\
\hline
\end{tabular}


As can be seen from Table 1, the typical content of a retailing course - as reflected in the topic list of a leading retailing text - serves to reinforce, through rolling repetition, content that is covered in several courses in marketing. The content of a retailing course has considerable cross-functional relevance, with topics in common with courses in multiple business disciplines. In addition, the content of a retailing course matches the learning areas specified by AACSB.

\section{SECONDARY AND INDIRECT OUTCOMES}

While the main benefits i.e., reinforcement of comprehensive, cross-functional learning and contribution to the fulfillment of AACSB learning goals have been discussed in the preceding section, there are several additional outcomes that may be of benefit to the school of business and department offering the retailing course, as well as to students taking the course.

\section{Introducing Non-Business Majors to the Business Disciplines}

Retailing as a subject of study is largely offered within colleges of business. However, programs outside the colleges of business also offer retailing related instruction (Mikitka and Stampfl 1994). Typically, it is in departments, such as Textiles and Clothing, Consumer and Family Services and Business Home Economics that retailing programs may be offered. However, it is also the case that majors in these non-business programs often take the retailing course(s) offered in colleges of business as electives. For such students, the retailing course may be the only business course they take. The retailing course thus provides an opportunity for introducing non-business students to the business discipline with considerable breadth of coverage. While this is likely to enhance the students' ability to take up positions in the retailing hierarchy, it also presents the opportunity to schools of business to attract non-business majors to take further business courses.

\section{Generating an Interest in Retailing Careers}

Historically, retailing as a career has suffered from a poor image and has had trouble attracting superior talent at the graduate entry level (Houlton and Thomas 1990; Howard 2004). The image of retail as a venue for hourly - and often minimum-wage - labor persists in spite of the growth in scale of retailing enterprises. Over three decades ago, Swerdlow (1978) had prognosticated the need for greater numbers of college graduates with coursework in marketing, training in human resource management, and written and oral communications skills, for staffing the growing retail sector. Retailers that are expanding, whether domestically or globally, are in need of qualified managerial talent, especially considering a high turnover rate historically found in the sector. Retailing education - along with work experience in retailing, consumer experience with retailers and family - contributes towards socialization of students and influences their propensity to opt for a career in retailing (Shim, Gehrt and Goldsberry 1999). Anderson, Stanley and Parker (1992) found academic influences to be the most significant of all types of influences on career choice of students. Thus, the retailing course has the potential to spark interest and build competence in candidates to the extent that they may consider a career in retailing upon graduation.

\section{Improving Consumer Education}

A retailing course provides a perspective on consumer behavior that is from the point of view of retailers who are seeking to influence buyers' decision-making through all the means available to them. Though these influence strategies and tactics are mostly ethical and legal, there are also some that may be border-line questionable. Through the retailing course, the student can be made aware of the role of merchandising, store layout, design and atmospherics, pricing and promotion strategies in attempting to influence retail buyer behavior. This awareness can contribute to students' consumer education as they become aware of the various influence strategies and are better informed of their choices. Consumer education has long been considered a means of reducing consumer dissatisfaction (Scherf 1974), and better informed consumers can therefore be in a position to reduce their own dissatisfaction with marketing institutions. 


\section{LIMITATIONS}

The potential for using the undergraduate retailing course for reinforcing comprehensive learning about the operations of a business are significant. However, there are also a few limitations that can hinder the achievement of this potential. To cover the content of a retailing course with thoroughness is desirable, so that the reinforcement and cross-functional learning can take place; however, the availability of class time during a typical three-credit hour course is limited. Due to this time limitation, instructors may not be able to do full justice to the course, with both breadth and depth of coverage. A second limitation may arise out of students' reluctance to apply themselves to certain parts of the course. For example, marketing majors, who have been found to be lacking in accounting and finance abilities, may attempt to skate through sections that have accounting or finance content, thus missing out on the reinforcement of learning they should have attained in the respective foundation courses. Similarly, students from other majors may attempt to skate through section of marketing content that they may consider irrelevant. With the availability of multiple components of evaluation, students can strategically skate through sections of courses without seriously affecting their grade in the course. A third limitation may be the instructor's lack of aptitude or interest in covering the cross-functional content of the course, leading them to skim over some of these crossfunctional sections. If the retailing course attracts non-business majors, it is possible that two strata of performance will emerge - one comprised of business students familiar (to some degree) with much of the content, and the other comprised of non-business majors whose lack of familiarity with business curricular content may place them at a disadvantage in learning. While it is desirable to ensure integrative learning, caution has been sounded against sacrificing the depth of learning in individual courses (Campbell, Heriot and Zachary 2006), and the instructor must ensure that the unique learning about retailing that is not found in other courses is not given short shrift in efforts to ensure reinforcement and cross-functional content. These and other possible limitations pose a challenge to the instructor: a challenge that is not insurmountable, but one that can be overcome with judicious and creative course planning.

\section{CONCLUSION}

A case has been made for utilizing the undergraduate retailing course to reinforce learning achieved in various marketing courses and to provide cross-functional learning, thereby developing an integrative understanding of business processes, activities and decision-making among business and non-business majors. While achieving these goals is not without limitations, overcoming the limitations can provide schools of business an excellent opportunity to improve the holistic learning and retention of business concepts among their students.

\section{AUTHOR INFORMATION}

Irfan Ahmed, Ph.D. is Assistant Professor of Marketing in the College of Business Administration at Sam Houston State University, Huntsville, Texas.

\section{REFERENCES}

1. AACSB, Eligibility Procedures and Accreditation Standards for Business Accreditation, http://www.aacsb.edu/accreditation/standards.asp, accessed December 4, 2008, 2008.

2. Abernethy, Avery M. and James I. Gray, Integrating Marketing and Financial Decision Making: Experiential Spreadsheet Applications, Marketing Education Review, Vol. 10, No. 1, pp. 35-45, 2000.

3. Ahadiat, Nas, In Search of Practice-Based Topics for Management Accounting Education, Management Accounting Quarterly, Vol. 9, No. 4, pp. 42-54, 2008.

4. Anderson, Carol H., Sande Richard Stanley and Thomas H. parker, Student Perceptions of Marketing Careers and Career Decision Influences: A Retailing Example, Journal of Marketing Education, Vol. 14, No. 1 , pp. 46-56, 1992.

5. Anderson, Nancy A., Educators' Identification of Salient Principles of Learning, Journal of Instructional Psychology, Vol. 17, No. 4, pp. 231-235, 1990.

6. Beachboard, John C. and David V. Beard, Innovation in Information Systems Education-II Enterprise IS Management: A Capstone Course for Undergraduate IS Majors, Communications of AIS, Vol. 15, pp. 315330,2005 
7. Behrman, Jack N. and Richard I. Lavin, Are Business Schools Doing Their Job? Harvard Business Review, Vol. 62, No. 1, pp. 240-248, 1984.

8. Berman, Barry and Joel R. Evans, Retail Management, $9^{\text {th }}$ ed., Englewood Cliffs, NJ: Prentice Hall, 2008.

9. Burns, Cathleen S., The Evolution of a Graduate Capstone Accounting Course, Journal of Accounting Education, Vol. 24, No. 2/3, pp. 118-133, 2006.

10. Bussière, Dave, Forensic Marketing: The Use of the Historical Method in a Capstone Marketing Course, Journal of Marketing Education, Vol. 27, No. 1, pp. 61-67, 2005.

11. Butler, Daniel and Katherine Straughn-Mizerski, Required and Elective Marketing Courses: How Far Have We Come in Twenty Years, Marketing Education Review, Vol. 8, No. 3, pp. 35-42, 1998.

12. Campbell, Noel D., Kirk C. Heriot and R. Zachary Finney, In Defense of Silos: An Argument Against the Integrative Undergraduate Business Curriculum, Journal of Management Education, Vol. 30, No. 2, pp. 316-332, 2006.

13. Coe, Barbara, Business School Faculty Beliefs About Retailing in the Business Curriculum, Journal of Retailing, Vol. 54, No. 3, pp. 45-52.

14. Corsini, Louis S., Victoria L. Crittenden, Richard C. Keeley, Gregory M. Trompeter and Barbara Viechnicki, Integrating Cross Functional Undergraduate Teaching and Learning: A Work in Progress, Marketing Education Review, Vol. 10, No. 3, pp. 1-17.

15. Cuganesan, Suresh, Calculating Customer Intimacy: Accounting Numbers in a Sales and Marketing Department, Accounting, Auditing and Accountability Journal, Vol. 21, No. 1, pp. 78-103, 2008.

16. Doyle Corner, Patricia, Stephen Bowden, Delwyn Clark, Eva Collins, Jenny Gibb, Kate Kearins, Kathryn Pavlovich, Grounded Learning from a Strategy Case Competition, Journal of Management Education, Vol. 30, No. 3, pp. 431-454, 2006.

17. Crittenden, Victoria L. and William F. Crittenden, The Undergraduate Capstone Marketing Course: Objectives, Content and Pedagogy, Journal for Advancement of Marketing Education, Vol. 8, No. 2, pp. 79-88, 2006.

18. Crittenden, Victoria L. and Elizabeth J. Wilson, An Exploratory Study of Cross-Functional Education in the Undergraduate Marketing Curriculum, Journal of Marketing Education, Vol. 28, No. 1, pp. 81-86, 2006.

19. DeConinck, James and Thomas Steiner, Developing an Integrated Finance and Marketing MBA Core Course, Journal of Marketing Education, Vol. 21, No. 1, pp. 44-50, 1999.

20. DeMoranville, Carol, Timothy W. Aurand and Geoffrey L. Gordon, The Delivery of an Undergraduate, Cross-Functional Business Principles Program: One University's Continuing Journey, Marketing Education Review, Vol. 10, No. 3, pp 29-41, 2000.

21. Dickinson, Roger A., The Future of Retail Education: Four Year Colleges, Journal of Retailing, Vol. 54, No. 3, pp. 87-93, 1978.

22. Eggen, Paul D. and Donald P. Kauchak, Strategies and Models for Teachers: Teaching Content and Thinking Skills, Boston: Allyn and Bacon, 2006.

23. Emery, Gary V., Integrating Production and Finance in the MBA Core Course, Financial Practice and Education, Vol. 7, No. 1, pp. 55-66, 1997.

24. Fang, Xiang, Sooun Lee, Ted. E. Lee and Wayne Huang, Critical Factors Affecting Job Offers for New MIS Graduates, Journal of Information Systems Education, Vol. 15, No. 2, pp. 190-204, 2004.

25. Gifford, Jack, Teaching Retail Financial Management to Marketing Majors, Journal of Marketing Education, Vol. 8, No. 4, pp. 33-40, 1986.

26. Houlton, Robert and Annette Thomas, Attracting Graduates to Retailing, International Journal of Retail \& Distribution Management, Vol. 18, No. 4, 12-19, 1990.

27. Hudson, Joseph L. Jr., What Should Be Emphasized in Retail Education? Journal of Retailing, Vol. 54, No. 3, pp. 67-70, 1978.

28. Howard, Elizabeth, Management in International Retailing, European Retail Digest, Issue 38, pp. 7-13, 2004.

29. Jervis, Kathryn J. and Carol A. Hartley, Learning to Design and Teach an Accounting Capstone, Issues in Accounting Education, Vol. 20, No. 4, pp. 311-339, 2005,

30. Kathryn J. Jervis and Carol A. Hartley, Learning to design and teach an Accounting Capstone, Issues in Accounting Education, Vol. 20, No. 4, pp 311-339, 2005. 
31. Kavanagh, Marie H. and Lyndal Drennan, What Skills and Attributes Does an Accounting Graduate Need? Evidence from Student Perceptions and Employer Expectations, Accounting \& Finance, Vol. 48, No. 2, pp. 279-300.

32. MacKay, Quinn G., Different Perspectives on Retail Education, Journal of Retailing, Vol. 54, No. 3, pp. 81-83, 1978.

33. Marcus, Stanley, Deficiencies in Retail Education, Journal of Retailing, Vol. 54, No. 3, pp. 77-80, 1978.

34. Marshall, Greg W., Steven E. Bolten and Paul J. Solomon, The Capstone "Integrated Business Applications" Course: Addressing the Need for Cross-Functional MBA Education, Marketing Education Review, Vol. 10, No. 3, pp. 63-75, 2000.

35. Mikitka, Kathleen Faith and Ronald F. Stampfl, Retailing in Marketing Education: Implications f CrossDisciplinary and Gender Diverse Programs, Journal of Marketing Education, Vol. 16, No. 1, pp. 25-33, 1994.

36. Mukherjee, Arup, Improving Student Understanding of Operations Management Techniques Through a Rolling Reinforcement Strategy, Journal of Education for Business, Vol. 77, No. 6, pp. 308-312, 2002.

37. Nofsinger, John R. Barbarians at the Gate: A capstone corporate finance course, Financial Practice \& Education, Vol. 5, No. 1, pp. 118-122, 1995.

38. Pearson, Michael M. and John Brockhoeft, The Legal Foundations of a Retail Transaction: Contract Law and the Uniform Commercial Code, Marketing Education Review, Vol. 10, No. 2, pp. 27-34, 2000.

39. Richey, R. Glenn, Lauren Skinner and Chad W. Autry, A Multilevel Approach to retail management Education: Integrating Customer and Supply Chain Perspectives, Marketing Education Review, Vol. 17, No. 2, pp. 28-43, 2007.

40. Seitz, Victoria and Nabil Razzouk, Teaching Retailing and Merchandising: An Experiential Approach, Marketing Education Review, Vol. 12, No. 1, pp. 53-60, 2002.

41. Scherf, Gerard W. H., Consumer Education as a Means of Alleviating dissatisfaction, Journal of Consumer Affairs, Vol. 8, No. 1, pp. 61-75, 1974.

42. Shim, Soyeon, Kenneth Gehrt and Ellen Goldsberry, Socialization Based Approach to Predicting Retail Career Preference and Choice, Journal of Marketing Education, Vol. 21 No. 1, 14-24, 1999.

43. Smart, Denise T., Chuck Tomkovick, Eli Jones and Anil Menon, Undergraduate Marketing Education in the $21^{\text {st }}$ Century: Views from Three Institutions, Marketing Education Review, Vol. 9, No. 1, pp 1-9, 1999.

44. Stanton, Angela D., A View from the Other Side: Customer Behavior from the Retailer's Perspective, Marketing Education Review, Vol. 16, No. 1, pp 71-74, 2006.

45. Swerdlow, Robert A., Retail Education in Four Year Institutions: What does the Future Hold? Journal of Retailing, Vol. 54, No. 3, pp. 37-44, 1978.

46. Wei, Kangning, Jane Siow and Diana L. Burley, Implementing Service-learning to the Information Systems and Technology Management Program: A study of an Undergraduate Capstone Course, Journal of Information Systems Education Vol. 18. No. 1, pp. 125-136, 2007. 